\title{
CLINICAL MANIFESTATIONS OF MIXED INFECTIONS BETWEEN ROTAVIRUSES AND OTHER INTESTINAL PATHOGENS
}

\author{
Ekaterina Vlkova, Margarita Gospodinova, Diana Radkova, Iliyan Todorov, \\ Veronika Gadzhovska, Minas Kozmidis, Guldjan Mollova
}

\author{
Department of Infectious diseases, Parasitology and Dermatology, Faculty of Medicine, \\ Medical University of Varna, Bulgaria
}

\begin{abstract}
INTRODUCTION: Rotaviruses are a leading cause of diarrheal mortality in children less than five years old. Mixed forms with other intestinal pathogens have been reported, interfering with the severity and outcome of the illness.

AIM: The aim of this article is to analyze the characteristics of mixed infections among rotaviruses and other intestinal pathogens.

MATERIALS AND METHODS: Twenty-seven patients up to 5 years of age, diagnosed with a co-infection from the rotavirus group and other intestinal pathogens were analyzed during the period from March, 2016 to December, 2017. A clinical epidemiologic study was conducted. The diagnosis was made by stool cultures for bacterial pathogens/feces analyses for viral antigens in the microbiology/virus laboratory of the St. Marina University Hospital, Varna. Statistic methods were used for data processing.

RESULTS: For the aforementioned period, 483 patients, up to 5 years of age, with rotaviral gastroenteritis were hospitalized. Mixed forms of intestinal infection were registered in 27 children (5.59\%). Early childhood (between 1 to 3 years of age) was the most commonly affected age group. Cases were separated into two groups: rotavirus-virus association and rotavirus-bacterium association. Cases with rotavirus-virus association were more predominant $(55.6 \%)$ than rotavirus-bacterium ones $(44.4 \%)$. The clinical presentation included fever, vomiting, diarrhea, and lasted $6.53 \pm 1.53$ days among the patients in the first studied group. In rotavirus-bacterium mixed infections vomiting was not a generally present symptom, but distinct complications ordinary occurred (83.33\%) and the average hospitalization period was $10 \pm 1.98$ days.
\end{abstract}

CONCLUSION: Mixed infections including rotavirus and other intestinal pathogens are rarely diagnosed and mainly affect young children. Compared with rotavirus-bacterium association, rotavirus-virus association is more commonly registered, its clinical course is milder, the prognosis of the disease is auspicious and the in-patient stay is shorter.

Keywords: rotavirus, mixed infections, children, gastroenteritis, dehydration

Address for correspondence:

Ekaterina Vlkova

Faculty of Medicine

Medical University of Varna

55 Marin Drinov St

9002 Varna

e-mail:evalkova83@gmail.com

Received: November 19, 2018

Accepted: December 28, 2018

\section{INTRODUCTION}

Infectious diarrhea continues to be an actual problem of modern medicine -2.7 billion cases are registered globally on an annual basis, of which 1.7 billion have a lethal outcome. The main risk group includes children under 5 years of age, in whom the intestinal infections become the reason for death in $9 \%$ of the cases (1). 
In developed countries, viruses cause about $70 \%$ of episodes of infectious diarrhea, while bacteria and parasites lead to diarrhea in $20 \%$ and $10 \%$ of the cases, respectively (2). Regardless of the World Health Organization's (WHO) recommendation from 2009 on the global use of the rotavirus vaccine (3), rotaviruses (RVs) continue to cause the majority of cases of viral gastroenteritis in children on a global scale (4). In Europe, this leads to approximately 75,000150,000 hospitalizations of children under 5 years of age annually (5). In Bulgaria, the aforementioned tendency is preserved. In a study conducted by Mladenova $\mathrm{Z}$ et al. on hospitalized children under 3 years of age with acute diarrhea, viruses caused diarrhea in $75 \%$ of the cases, $62 \%$ of which were diagnosed as rotaviral gastroenteritis (RGE) (6). In a study by Stoeva $\mathrm{T}$ et al. the incidence of viral causative agents in positive stool samples accounted for $66.7 \%$, with leading share of RV - 50\%, and the mixed types of intestinal infections were present in $4.87 \%$ of stool samples of children under 5 years of age (7).

As a result of the advancement of laboratory techniques, a high occurrence of RV co-infections with other enteropathogens has been established: bacteria, viruses, and parasites. Their incidence varies widely from 0.3 to $45.5 \%$ depending on the geographical features, economic development, and sanitary culture of a given country, employed laboratory techniques and characteristics of the studied population (8). In Bulgaria, epidemiologic studies have established that the mixed types of intestinal infections in children under 3 years of age account for $27 \%$ of the cases with identified causative agent (6).

In Europe, the mortality rate caused by RGE is at a low level: 0.1-0.2/100,000 (5). Moreover, complicated variants of infection with severe course, which require long hospitalization, are present in over 15\% of the cases (9). We have limited information about risk factors leading to complicated cases. The studies have proved the effect of the following: low body weight at birth, a nursery or preschool attendance and another child under 2 years of age in the family $(10,11,12)$.

Irrespective of the high level of distribution of RV co-infections, studies reporting the characteristics of their clinical course and degree of complexity of a certain type of infection are limited and di- verging. The demonstrated data vary from the lack of a synergistic effect between RV and other intestinal pathogens $(6,13,14)$ to substantial presence of synergism between them $(15,16)$. The answer about the possibility for such interaction was sought in the tests on cell cultures and animalistic models. The majority of the in vitro experiments show that the co-infection of the cells with RV and various bacterial enteropathogens leads to an increase in bacterial invasiveness and their replication capacity $(17,18,19)$, since RVs cause disorganization in the components of the cytoskeleton in intestinal cells (20).

Undoubtedly, mixed infections and their complex role in the pathogenesis of human diseases need additional research, especially when it comes to socially significant diseases on a global scale, such as rotavirus infections.

\section{AIM}

To study the clinical course of mixed forms of RV infections with other viral and bacterial enteropathogens in children under 5 years of age, suffering from infectious diarrhea, we set the following tasks:

1. to obtain the frequency of occurrence of mixed forms of the infection: rotavirus-virus (RVVA) and rotavirus-bacterium associations (RVBA);

2. to study the characteristics of the course of RV co-infections, depending on the co-infecting agent.

\section{MATERIALS AND METHODS}

The disease history of 27 children aged 0 to 5 years with mixed forms of RV infection with viral and bacterial enteropathogens, who were hospitalized in the Infectious Disease Clinic at Saint Marina University Hospital, Varna in the period March, 2016 - December, 2017, was analyzed retrospectively. Their diagnoses were confirmed through culture methods for bacterial causative agents and immunochromatographic methods for the viral ones. The clinical manifestations and laboratory changes in the course of the infectious disease in every patient were studied. Records from the medical databases of the clinic for the hospitalized patients in the period were used. 


\section{RESULTS}

Six hundred eighteen children aged 0 to 5 years with acute intestinal infections were treated during 10 months of 2016, 211 (34.14\%) of them were diagnosed with RGE, in $5(0.81 \%)$ cases mixed forms of the RV infection were observed. In 2017, out of a total of 615 children RGE was confirmed for 245 (39.84\%) children, and the mixed forms were reported in 27 (3.58\%) of them (Fig. 1). The cases of mixed infections were registered throughout the year. As evident from the case history, all 27 children had been vaccinated in compliance with the Vaccine Schedule of the Republic of Bulgaria, but the specific vaccination against RV was never administered to any of them.

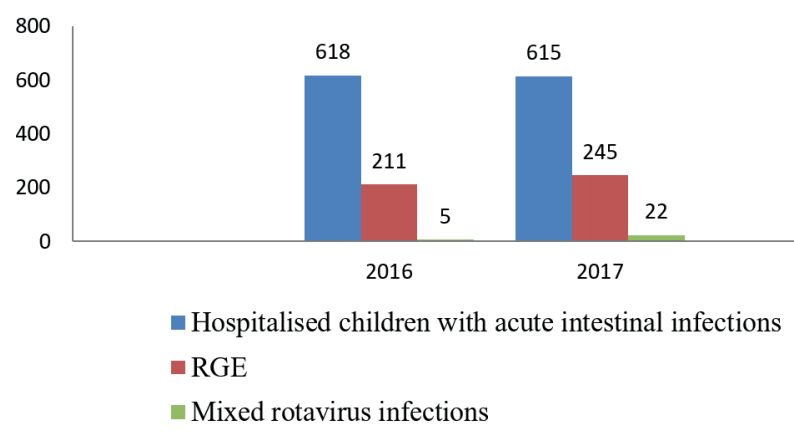

Fig. 1. The incidence of RV mono- and co-infections in the structure of acute intestinal infections in children aged 0 - 5 years

The mixed forms comprised an association of a rotavirus with another enteropathogenic virus or bacterium. According to this indication, the patients were divided into two groups: with RVVA (15 patients $-55.6 \%)$ and with RVBA (12 patients $-44.4 \%$ ) (Fig. 2).

In addition to RV in RVVA patients, we established the presence of adenovirus in 6 patients

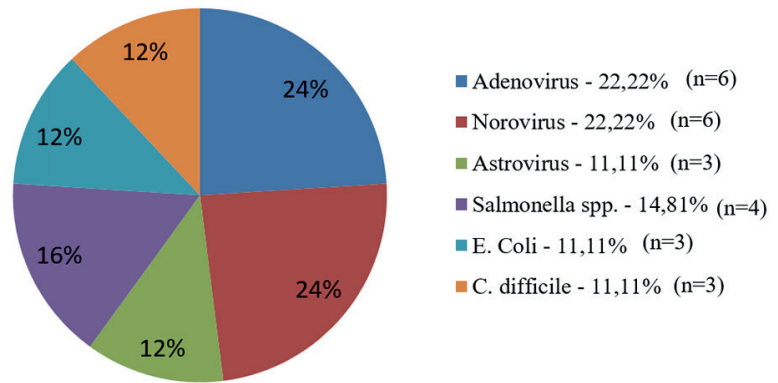

Fig. 2. Distribution of the patients according to the type of co-infecting agent
(22.22\%), norovirus in 6 patients (22.22\%), and astrovirus in 3 patients (11.11\%). In 3 cases, more than 2 pathogens were identified (20\%). The co-infecting agents in RVBA were as follows: Salmonella spp. in 4 patients (14.81\%), E. coli in 3 patients (11.11\%), toxigenic strain of C. difficile in 3 patients (11\%), and Shigella spp. in 2 patients (7.41\%).

According to their age, the distribution of the patients was as follows:

$\diamond$ patients with RVVA aged 0 to $1: 6(40 \%)$, from 1 to 3 years old: 7 (46.67\%), from 3 to 5 years old: $2(13.33 \%)$;

$\diamond$ patients with RVBA aged 0 to $1: 2$ (16.67\%), from 1 to 3 years old: 8 (66.67\%), from 3 to 5 year old: 2 (16.67\%) (Fig. 3).

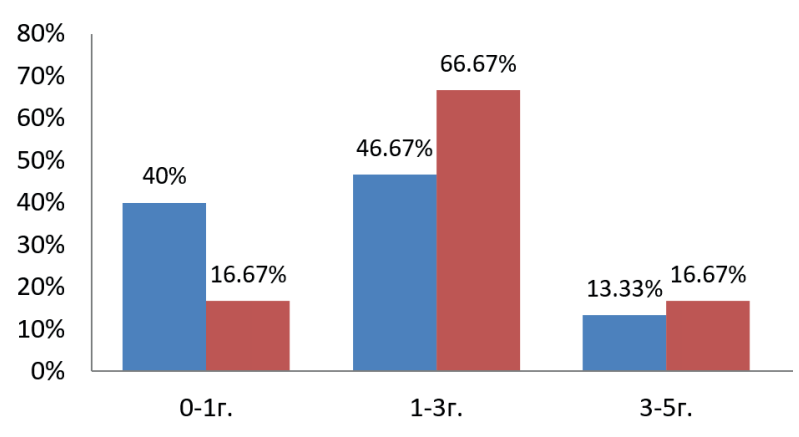

Fig. 3. Age distribution of patients

We also calculated the average age of the patients depending on the type of co-infecting agent. The patients with RVVA were aged $20 \pm 14.3$ months on average, and those with RVBA - 25 \pm 15.8 months.

The clinical manifestations of mixed infections in patients with RVVA and RVBA were studied. We established that the course of RVVA included fever, watery diarrhea and vomiting in 10 patients $(66.67 \%)$, watery diarrhea and vomiting in 4 patients (26.67\%), watery diarrhea and fever in only 1 patient (6.67\%). RVBA patients were characterized by fever, watery diarrhea and vomiting in 5 cases (41.67\%), watery diarrhea and vomiting in 2 patients (16.67\%), watery diarrhea and fever in 5 patients (41.67\%) (Fig. 4). Moreover, we found differences in the average temperature upon admission: in patients with RVVA $37.9 \pm 1.1^{\circ} \mathrm{C}$, and in patients with RVBA $-38.3 \pm 0.97^{\circ} \mathrm{C}$. The frequency of the main occurrences of intestinal infection in the two groups in the first 24 hours was analyzed. In patients with RVVA the average number 
Ekaterina Vlkova, Margarita Gospodinova, Diana Radkova et al.

of vomits in the first 24 hours was $5.4 \pm 3.4$, and the average number of defecations $-6.4 \pm 3$.3. In patients with RVBA the tendency was as follows: the frequency of vomits equaled $2.42 \pm 3.1$, whereas the average number of defecations was $6.33 \pm 3.1$, and half of our patients complained of abdominal pain and presence of mucus and/or blood in the stool (50\%).

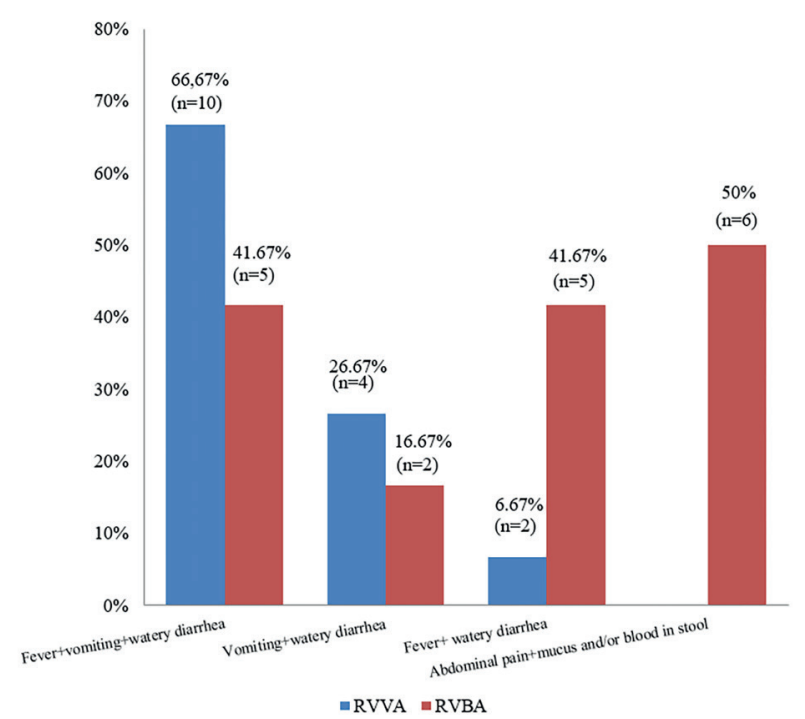

Fig. 4. The clinical manifestations of $R V$ infections, according to the type of co-infecting agent

We compared the length of the hospital stay as well, depending on the type of co-infecting agent. In the case of RVVA it was from 0 to 5 days for 8 patients (53.33\%), between 6 and 10 days for 5 patients (33.33\%) and over 10 days for 2 (13.33\%). The average hospital stay in this category was $6.53 \pm 3.46$ days. The following was observed in the case of RVBA: only one patient $(8.33 \%)$ stayed in hospital for 5 days, 7 patients (58.33\%) - between 6 and 10 days, 4 patients (33.33\%) - over 10 days (Fig. 5). The average hospital stay of patients with RVBA was $10.1 \pm 3.73$ days.

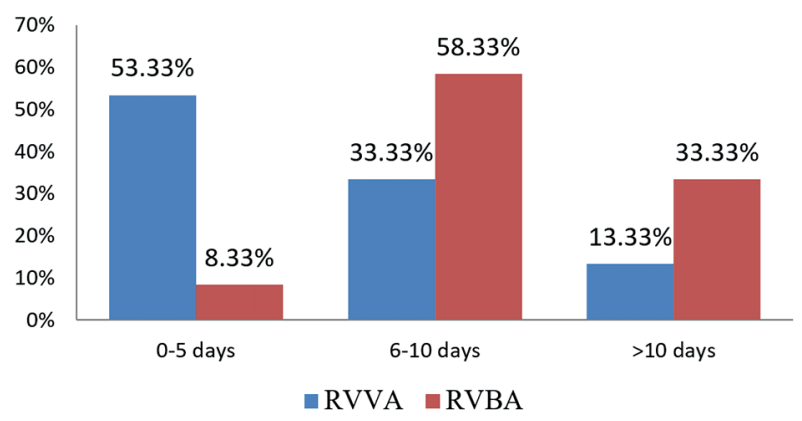

Fig. 5. Length of hospital stay
Presence of deviations in the acid-base balance $(\mathrm{ABB})$ and the fluid and electrolyte balance (FEB) in our patients was analyzed and the following tendency was identified. Four patients $(26.67 \%)$ with RVVA had no changes in $\mathrm{ABB}$ and $\mathrm{FEB}$, in 8 patients (53.33\%) we observed data for decompensated metabolic acidosis (DMA), 2 patients (13.33\%) demonstrated data for hypokalemia, and 1 patient $(6.67 \%)$ data for hypochloremia. In the patients with RVBA: no complications regarding $\mathrm{ABB}$ and $\mathrm{EB}$ were observed in 2 patients (16.67\%), with data for DMA were 5 patients (41.67\%), hypokalemia was present in 2 patients (16.67\%), and 3 patients (25\%) had hyponatremia (Fig. 6).

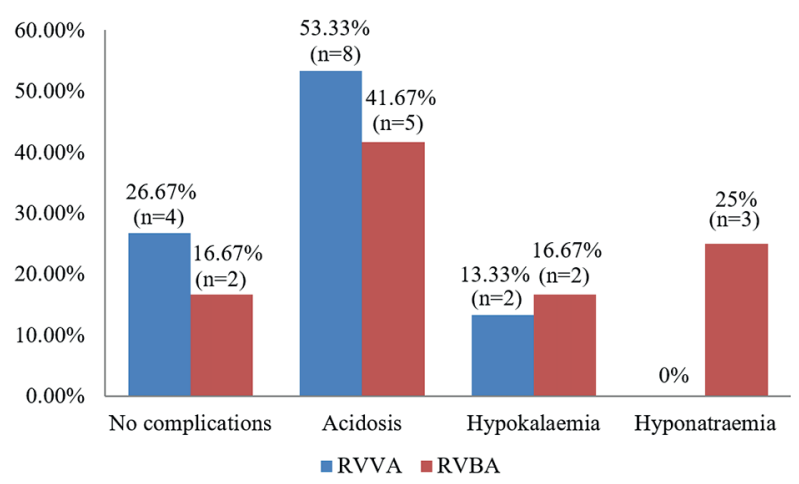

Fig. 6. Changes in $A B B$ and FEB in patients with RVVA and $R V B A$

The differences in markers of acute inflammation in our patients were reported. In patients with RVVA the average leukocyte count was $9.91 \pm 5.2 \cdot 10^{\%} / \mathrm{L}$, and the values of C-reactive protein (CRP) equaled $9.07 \pm 11.86 \mathrm{mg} / \mathrm{L}$. In the patients with RVBA, the average leukocyte count was $14.12 \pm 5.1 \cdot 10^{9} / \mathrm{L}$, and CRP values were $31.5 \pm 48.59 \mathrm{mg} / \mathrm{L}$.

\section{DISCUSSION}

In the period from March, 2016 to December, 2017 there were 1,233 children with acute intestinal infections under 5 years of age treated at the Infectious Disease Clinic in Varna. Four hundred fiftysix children (36.98\%) were diagnosed with RGE, and the diagnosis for mixed forms of RV infections with other intestinal enteropathogens was reported in 27 cases (5.92\%). The data correlates with global, European and national tendencies, where RVs are the main causative agents of gastroenteritis in children under 5 years of age $(4,21,22)$, and the frequency of 
occurrence of mixed infections with other intestinal pathogens is directly dependent on the sanitary and hygiene conditions of life in a given country and varies widely (8). Sixteen (59.26\%) of the patients studied by us belong to a part of the population with poor social and living conditions and low sanitary and hygiene culture.

The etiological diversity of viral and bacterial co-infecting enteropathogens in our study most probably projects their epidemiological significance to Bulgaria as a developed country in the European Union. The number of patients with intestinal infections as a result of the mixed infection of RV with another viral enteropathogen prevail over the cases of mixed infections with bacterial enteropathogens (55.6\% and $44.4 \%$ respectively), similarly to other developed countries - the viruses, as causative agents of intestinal infections, prevail over the bacterial enteropathogens in children under 5 years of age $(2,22)$.

In the structure of incidence of intestinal infections, rotaviruses lead in terms of frequency of occurrence, followed by adenovirus, norovirus and astrovirus $(23,24)$, with the exception of countries with high exposure of the population to the rotavirus vaccine, where norovirus has a leading role $(25,26)$. Analogically, the presence of such co-infecting bacterial enteropathogens, which are epidemiologically significant to Europe: Salmonella spp., E. coli, C. difficile, Shigella spp., was established. The exception, which we determined contrary to the aforementioned tendency, is the lack of Campylobacter spp., which causes the most common zoonosis in the EU, among the isolates (27). The authors explain this fact with characteristics of the cultivation of Campylobacter spp. Their requirements to the growing medium are higher, and their growth is slower compared with other enterobacteria, which limits the routine study of this pathogen in every patient with infectious diarrhea (28).

The age distribution of the patients in our study does not differ from the generally known scientific data: according to the European Centre for Disease Prevention and Control (ECDC), RGE are mostly seen in children under 3 years of age (4). The majority of the patients with the mixed forms of RGE with a bacterial enteropathogen belong to the age group of 1-3 years, unlike the cases of mixed forms of RGE with another viral enteropathogen, where the distribution of patients from age groups $0-1$ years and 1-3 years is almost uniform. The authors presume this fact is explained with the characteristics related to raising children: stricter hygiene, a narrower circle of contact people for infants and passive immunity in the first month of their life. By expanding the diet and increasing the contacts, the opportunity for encountering a bacterial enteropathogen increases considerably. In addition, the fact that 23 out of 27 studied patients were aged $0-3$ confirms the scientific data for complicated RGE course which requires hospitalization (both in monoinfections and mixed form cases) in children under 3 years of age $(10,11,12)$.

The clinical characteristics of RGE normally include a general toxic and infectious syndrome (with insignificantly expressed temperature response), as well as upper and lower dyspeptic syndromes (potentially leading to dehydration and dyselectrolytemia) (29). Similar clinical indicators at a different level of manifestation are also observed in the patients with infectious diarrhea of noro-, adeno- and astroviral origin $(30,31,32)$. Respectively, all our patients with mixed forms of RV infections with other viral enteropathogens complained of the symptoms above. Making a comparison with patients from another group, we also established another symptom in half of them - abdominal pain, and diarrhea stools containing mucus and/or blood, which is typical of bacterial enteropathogens. Furthermore, a difference in the intensity of the main symptoms in the two groups in the first 24 hours after the admission was noticed. In almost equal number of defecations $(6.4 \pm 3.3$ and $6.33 \pm 3.1$ respectively), the patients suffering from mixed RV infection with another viral enteropathogen had more cases of vomiting $(5.4 \pm 3.4$ compared to $2.42 \pm 3.1)$ and not so expressed temperature response $\left(37.9 \pm 1.1^{\circ} \mathrm{C}\right.$ compared to $\left.38.3 \pm 0.97^{\circ} \mathrm{C}\right)$.

Both groups of studied patients demonstrated deviations from $\mathrm{ABB}$ and FEB (mainly in the patients from the second group with a bacterial co-infecting enteropathogen). However, in our opinion, this fact is not due to the presence of the mixed infection, as an aggravating factor, but is explained by the characteristics of the studied sample of patients with the available symptoms for hospitalization at the Infectious Disease Clinic. 
Ekaterina Vlkova, Margarita Gospodinova, Diana Radkova et al.

RGE is a self-limiting disease whose duration is between 5 and 8 days (5). In 2012-2014, Gospodinova $\mathrm{M}$, Todorov I et al., conducting a study on rotavirus infections, reported an average hospital stay of such patients of $6.37 \pm 1.21$ days (33). In the present study, a similar result was obtained in patients with mixed forms of viral gastroenteritis ( $6.53 \pm 3.46$ days). A different result was obtained for patients with mixed forms of RV infections with bacterial enteropathogens: the symptoms in them persisted longer, and the average hospital stay was $10.1 \pm 3.73$ days.

The treatment administered to all patients included parenteral rehydration therapy and probiotics. The changes in ABB and FEB were adjusted when necessary. The antibiotic therapy (according to an antimicrobial susceptibility testing) was administered to those patients with RVBA who had a colitis syndrome during the clinical course of the disease.

None of our patients had an RV vaccination. The positive effect of the specific immunization has already been proven conclusively $(3,4,5)$, but it is an interesting fact that a number of studies reported the benefit of the administration of the RV vaccine in cases of infection with another intestinal enteropathogen $(34,35)$. In a placebo-controlled study by Pang XL et al. on children aged 50-110 days, 86 of 1,528 episodes of diarrhea were predetermined by a monoinfection with adenoviruses and 12 - by mixed rotavirus-adenovirus infections. Compared to the placebo group, the children vaccinated against RV had shorter diarrhea duration, even in the cases with adenoviral etiology of the disease (34). Similar results were also obtained in the course of another study, where sapovirus-associated gastroenteritis cases had a considerably milder course in children vaccinated against $R V$ (35).

\section{CONCLUSIONS}

In our study, we established that RGE still accounts for a significant incidence of the pathology of intestinal infections in children under 5 years of age. Commonly mixed forms with other enteropathogens are registered. In our study the mixed forms of intestinal infection were registered in 5.59\% of cases. The early childhood period is mostly affected with a prevalence of RVVA. The most common pathogens in mixed forms are adenovirus, norovirus and Salmonella spp. Leukocytosis and increased CRP re- fer to RVBA. Complicated clinical course and longer hospital stay were observed in patients with RVBA with characteristic symptoms: body temperature $>38.3^{\circ} \mathrm{C}$; abdominal pain, blood and/or mucus in stool; the level of social and living conditions influences the diagnosis as well. Compared with RVBA, RVVA are commonly registered, their clinical course is milder, the prognosis of the disease is auspicious and the in-patient stay is shorter.

Respectively, the wide immunization of children with a RV vaccine can contribute considerable benefits to society. Further studies would be useful in order to assess the effect of immunization on the mixed forms of RV infection.

The limited number of studied patients did not allow us to make a comparison between the clinical course of RGE as a monoinfection and the mixed forms of RGE with other enteropathogens. As a result, a question remained unanswered: do intestinal pathogens act in synergy or antagonistically and, respectively, how the presence of another enteropathogen complicates RGE? Further studies are necessary for a clearer understanding of this type of infection.

\section{Conflict of Interest Statement:}

The authors declare that there is no conflict of interest.

The authors received no specific funding for this work.

\section{REFERENCES}

1. Vlkova E, Gospodinova M, Todorov I. Fecal calprotectin in the differential diagnosis of acute intestinal infections. J Infectol. 2018;10(2):117-22. (In Russian)

2. Radlovic N, Lekovic Z, Vuletić B, Radlović V, Simic D. Acute diarrhea in children. Srp Arh Celok Lek. 2015; 143(11-12):755-62.

3. World Health Organization, PATH, GAVI Alliance: WHO Recommends Global Use of Rotavirus Vaccines. Geneva and Seattle; 2009 [updated 2009; cited]; Available from: http://www.rotavirusvaccine.org/files/WHO_GAVI_PATH_Press-Releaseon-SAGE_FINAL_4June09_000.pdf

4. European Centre for Disease Prevention and Control. Impact of rotavirus vaccination - Generic study protocol. Stockholm: ECDC; 2013. 
5. European Centre for Disease Prevention and Control. ECDC Expert opinion on rotavirus vaccination in infancy. Stockholm: ECDC; 2017

6. Mladenova Z, Steyer A, Steyer A, Ganesh B, Petrov $\mathrm{P}$, Tchervenjakova T, et al. Aetiology of acute paediatric gastroenteritis in Bulgaria during summer months: prevalence of viral infections. J Med Microbiol. 2015; 64(3):272-82. doi: 10.1099/ jmm.0.000018.

7. Stoeva T, Bozhkova M, Dimitrova D, Kujumdzhieva G, Snegarova V, Markovska R. Etiologichen spektar na infekciite na gastrointestinalen trakt pri pacienti, hospitalizirani v UMBAL «Sveta Marina»Varna. Varnenski medicinski forum. 2017;6(2): 3541. (in Bulgarian)

8. Grimprel E, Rodrigo C, Desselberger U. Rotavirus Disease: Impact of Coinfections. Pediatr Infect Dis J. 2008; 27(1):3-10. doi: 10.1097/ INF.0b013e31815eedfa.

9. Johansen $\mathrm{K}$, Hedlund $\mathrm{KO}$, Zweygberg-Wirgart $\mathrm{B}$, Bennet R. Complications attributable to rotavirus-induced diarrhoea in a Swedish paediatric population: Report from an 11-year surveillance. Scand J Infect Dis. 2008;40(11-12):958-64. doi: 10.1080/00365540802415509.

10. Huppertz HI, Salman N, Giaquinto C. Risk factors for severe rotavirus gastroenteritis. Pediatr Infect Dis J. 2008;27(1 Suppl.):11-9. doi: 10.1097/ INF.0b013e31815eee0a

11. Adlhoch $C$, Hoehne M, Littmann M, Marques AM, Lerche A, Dehnert M, et al. Rotavirus vaccine effectiveness and case - control study on risk factors for breakthrough infections in Germany, 20102011. Pediatr Infect Dis J. 2013;32(2):e82-e9. doi: 10.1097/INF.0b013e3182720b71.

12. Dennehy $P$, Cortese $M$, Bégué R, Jaeger J, Roberts N, Zhang R, et al. A case-control study to determine risk factors for hospitalization for rotavirus gastroenteritis in U.S. children. Pediatr Infect Dis J. 2006;25(12):1123-31. doi: 10.1097/01. inf.0000243777.01375.5b.

13. Unicomb LE, Faruque SM, Malek MA, Faruque AS, Albert MJ. Demonstration of a lack of synergistic effect of rotavirus with other diarrheal pathogens on severity of diarrhea in children. J Clin Microbiol. 1996;34(5):1340-2.

14. Wei-Te L, Pei-Chen L, Lung-Chang L, Hsiu-Lin C, Rei-Cheng Y, Salmonella/rotavirus coinfection in hospitalized children.
15. Kaohsiung J Med Sci. 2012; 28(11):595-600. doi: 10.1016/j.kjms.2012.04.025.

16. Zhang SX, Zhou YM, Xu W, Tian LG, Chen JX, Chen $\mathrm{SH}$, et al. Impact of co-infections with enteric pathogens on children suffering from acute diarrhea in southwest China. Infect Dis Poverty. 2016;5:64. doi:10.1186/s40249-016-0157-2.

17. Bhavnani D, Goldstick JE, Cevallos W, Trueba G, Eisenberg JN. Synergistic effects between rotavirus and coinfecting pathogens on diarrheal disease: evidence from a community-based study in northwestern Ecuador. Am J Epidemiol. 2012;176(5):38795. doi: 10.1093/aje/kws220.

18. Bukholm G. Human rotavirus infection enhances invasiveness of enterobacteria in MA-104 cells. APMIS. 1988;96:1118-24.

19. Di Biase AM, Petrone G, Conte MP, Seganti L, Ammendolia MG, Tinari A, et al. Infection of human enterocyte-like cells with rotavirus enhances invasiveness of Yersinia enterocolitica and Y. pseudotuberculosis. J Med Microbiol. 2000;49(10):897-904. doi: 10.1099/0022-1317-49-10-897.

20. Superti F, Petrone G, Pisani S, Morelli R, Ammendolia MG, Seganti L. Superinfection by Listeria monocytogenes of cultured human enterocyte-like cells infected with poliovirus or rotavirus. Med Microbiol Immunol (Berl). 1996;185(3):131-7.

21. Zambrano JL, Sorondo O, Alcala A, Vizzi E, Diaz Y, Ruiz MC, et al. Rotavirus infection of cells in culture induces activation of RhoA and changes in the actin and tubulin cytoskeleton. PLoS One. 2012;7(10):e47612. doi:10.1371/journal. pone.0047612.

22. European Society for Pediatric Gastroenterology, Hepatology, and Nutrition/European Society for Pediatric Infectious Diseases Evidence-Based Guidelines for the Management of Acute Gastroenteritis in Children in Europe: Update 2014. JPGN. 2014; 59: 132-152.

23. Stoyanova K, Cvetkova T. Point prevalence of intestinal parasites in hospitalized and outpatients with diarrhea. Probl Infect Parasit Dis. 2017; 45(1): 41-6.

24. Operario DJ, Platts-Mills JA, Nadan S, Page N, Seheri M, Mphahlele J, et al. Etiology of severe acute watery diarrhea in children in the Global Rotavirus Surveillance Network using quantitative PCR. J Infect Dis. 2017; 45(2): 220-7. doi: 10.1093/infdis/ jix294. 
Ekaterina Vlkova, Margarita Gospodinova, Diana Radkova et al.

25. Wang X, Wang J, Sun H, Xia S, Duan R, Liang J, et al. Etiology of childhood infectious diarrhea in a developed region of China: Compared to childhood diarrhea in a developing region and adult diarrhea in a developed region. PLoS ONE. 2015; 10(11): e0142136. doi: 10.1371/journal.pone.0142136.

26. Payne DC, Vinje J, Szilagyi PG, Edwards KM, Staat MA, Weinberg GA, et al. Norovirus and medically attended gastroenteritis in U.S. children. N Engl J Med. 2013;368(12):1121-30. doi: 10.1056/ NEJMsa1206589.

27. Hemming M, Rasanen S, Huhti L, Paloniemi M, Salminen M, Vesikari T. Major reduction of rotavirus, but not norovirus, gastroenteritis in children seen in hospital after the introduction of RotaTeq vaccine into the National Immunization Programme in Finland. Eur J Pediatr. 2013;172(6):739_ 46. doi: 10.1007/s00431-013-1945-3.

28. EFSA (European Food Safety Authority) and ECDC (European Centre for Disease Prevention and Control), 2016. The European Union summary report on trends and sources of zoonoses, zoonotic agents and food-borne outbreaks in 2015. EFSA J. 2016;14(12):4634, 231 pp.

29. Tam C, O’Brien S, Tompkins D, Bolton F, Berry L, Dodds J, et al. Changes in causes of acute gastroenteritis in the United Kingdom over 15 years: microbiologic findings from 2 prospective, population-based studies of infectious intestinal disease. Clin Infect Dis. 2012; 54(9):1275-86. doi: 10.1093/ cid/cis028.

30. Bernstein DI. Rotavirus overview. Pediatr Infect Dis J. 2009; 28(3 Suppl):50-3.

31. Klinicheskie rekomendacii (protokol lechenija) okazanija medicinskoj pomoshhi detjam bol'nym norovirusnoj infekciej. FGBU NIIDI FMBA Rossii,
Obshhestvennaja organizacija «Evroaziatskoe obshhestvo po infekcionnym boleznjam» Obshhestvennaja organizacija «Associacija vrachej infekcionistov Sankt-Peterburga i Leningradskoj oblasti» (AVISPO). 2015g. (in Russian)

32. Klinicheskie rekomendacii (protokol lechenija) okazanija medicinskoj pomoshhi detjam bol'nym adenovirusnym gastrojenteritom. FGBU NIIDI FMBA Rossii, Obshhestvennaja organizacija «Evroaziatskoe obshhestvo po infekcionnym boleznjam», Obshhestvennaja organizacija «Associacija vrachej infekcionistov Sankt-Peterburga i Leningradskoj oblasti» (AVISPO). 2015g. (in Russian)

33. Klinicheskie rekomendacii (protokol lechenija) okazanija medicinskoj pomoshhi detjam bol'nym astrovirusnym gastrojenteritom. FGBU NIIDI FMBA Rossii, Obshhestvennaja organizacija «Evroaziatskoe obshhestvo po infekcionnym boleznjam», Obshhestvennaja organizacija «Associacija vrachej infekcionistov Sankt-Peterburga i Leningradskoj oblasti» (AVISPO). 2015g. (in Russian)

34. Gospodinova M, Todorov I, Todorova I, Mollova G, Kozmidis M. Rotavirusni infekcii pri hospitalizirani deca v Infekciozna klinika - Varna. Nauka Infektologija i parazitologija. 2015; 2(11): 21-4.(in Bulgarian.)

35. Pang XL, Koskenniemi E, Joensuu J, Vesikari T. Effect of rhesus rotavirus vaccine on enteric adenovirus-associated diarrhea in children.

J Pediatr Gastroenterol Nutr. 1999;29(3):366-9.

36. Pang XL, Zeng SQ, Honma S, Nakata S, Vesikari T. Effect of rotavirus vaccine on Sapporo virus gastroenteritis in Finnish infants. Pediatr Infect Dis J. 2001;20(3):295-300. 